\title{
Insufficient natural killer cell responses against retroviruses: how to improve NK cell killing of retrovirus-infected cells
}

\author{
Elisabeth Littwitz-Salomon ${ }^{*}$, Ulf Dittmer ${ }^{\dagger}$ and Kathrin Sutter ${ }^{\dagger}$
}

\begin{abstract}
Natural killer (NK) cells belong to the innate immune system and protect against cancers and a variety of viruses including retroviruses by killing transformed or infected cells. They express activating and inhibitory receptors on their cell surface and often become activated after recognizing virus-infected cells. They have diverse antiviral effector functions like the release of cytotoxic granules, cytokine production and antibody dependent cellular cytotoxicity. The importance of NK cell activity in retroviral infections became evident due to the discovery of several viral strategies to escape recognition and elimination by NK cells. Mutational sequence polymorphisms as well as modulation of surface receptors and their ligands are mechanisms of the human immunodeficiency virus-1 to evade NK cellmediated immune pressure. In Friend retrovirus infected mice the virus can manipulate molecular or cellular immune factors that in turn suppress the NK cell response. In this model NK cells lack cytokines for optimal activation and can be functionally suppressed by regulatory T cells. However, these inhibitory pathways can be overcome therapeutically to achieve full activation of NK cell responses and ultimately control dissemination of retroviral infection. One effective approach is to modulate the crosstalk between NK cells and dendritic cells, which produce NK cell-stimulating cytokines like type I interferons (IFN), IL-12, IL-15, and IL-18 upon retrovirus sensing or infection. Therapeutic administration of IFNa directly increases NK cell killing of retrovirus-infected cells. In addition, IL-2/anti-IL-2 complexes that direct IL-2 to NK cells have been shown to significantly improve control of retroviral infection by NK cells in vivo. In this review, we describe novel approaches to improve NK cell effector functions in retroviral infections. Immunotherapies that target NK cells of patients suffering from viral infections might be a promising treatment option for the future.
\end{abstract}

\section{Background}

Despite more than 30 years of intensive research, HIV still represents a global health problem with up to 37 million HIV-infected people worldwide in 2015. After infection with HIV, the human immune system is not able to fully control the virus, which finally results in the development of the lethal acquired immunodeficiency syndrome (AIDS). HIV preferentially infects human leucocytes like macrophages and $\mathrm{T}$ cells carrying the surface protein CD4 and the co-receptor CXCR4 or CCR5. The progression to AIDS is accompanied with a decline in

\footnotetext{
*Correspondence: Elisabeth.Littwitz@uni-due.de

${ }^{\dagger}$ Elisabeth Littwitz-Salomon, Ulf Dittmer, and Kathrin Sutter contributed equally to this review

Institute for Virology, University Hospital in Essen, University of DuisburgEssen, Hufelandstr. 55, 45147 Essen, Germany
}

$\mathrm{CD}^{+} \mathrm{T}$ cell numbers. However, the reasons for the failure of the host immune system in HIV infection are complex. To date, there is no cure or vaccine available, but antiretroviral therapy (ART) can control the progression of the disease for decades.

To develop new strategies to combat retroviral infections, animal models are required to analyze host immune responses against retroviruses and their modulation by various immunotherapies. As mice cannot be infected with HIV-1, murine retroviruses should be used to discover basic concepts of innate and adaptive immunity in retroviral infections. The mouse model that has been used most intensively to study retroviral immunity in the past is the infection of mice with the Friend Retrovirus (FV) complex. The FV complex, consisting of the Friend murine leukemia virus (F-MuLV) and the Spleen 
focus-forming virus (SFFV), induces acute splenomegaly in susceptible mice due to a rapid polyclonal erythroblast proliferation and transformation, which is subsequently followed by the development of a lethal erythroleukemia [1]. However, resistant mouse strains mount a potent antiviral immune response during the acute phase of infection that can prevent the onset of leukemia [2]. Despite this initial viral control, FV eventually escapes from $\mathrm{T}$ cell mediated immunity and establishes a chronic infection [3]. This mouse model does not resemble pathological features of HIV-1 infection, but there are many similarities in innate and adaptive immune responses during HIV-1 and FV infection [4]. The development of chronic infection is associated with dysfunctionality of effector $\mathrm{CD}^{+} \mathrm{T}$ cells and the activation and expansion of regulatory T cells in HIV-1 and FV infection [5, 6]. NK cell responses were also shown to control acute infections with FV or HIV-1 [7, 8]. Thus, the FV model allows to study NK cell functions during acute retroviral infection in great detail and to therapeutically manipulate the NK cell response in retroviral infections in vivo.

\section{NK cell biology}

The first line of immune responses against viruses is mediated through innate immune cells. As a part of the innate immune system NK cells are responsible for early antiviral functions. NK cells express various germline-encoded inhibitory and activating receptors, like natural cytotoxicity receptors (NCRs), C-type lectin-like receptors and killer cell immunoglobulin-like receptors (KIRs) in humans and the corresponding Ly49 receptors in mice. A dysbalance of signals from these receptors can lead to activation of NK cells. NK cell effector functions include cytotoxicity and production of cytokines and chemokines. In humans, NK cells represent $2-18 \%$ of the lymphocytes in human peripheral blood [9] and are comprised of two main subsets, characterized by bright CD56 (CD56 $6^{\text {bright }}$ ) or low-density CD56 (CD56 $\left.{ }^{\mathrm{dim}}\right)$ expression [10]. CD56 ${ }^{\mathrm{dim}}$ NK cells constitute more than $90 \%$ of the NK cells in the peripheral blood and they are able to induce apoptosis of virus-infected cells by the release of granzymes and perforin or binding of ligands (TRAIL, FasL) to their death receptors (TRAIL-R, FasR). The majority of this NK cell subset expresses CD16 (Fcy receptor III) [10], which is necessary for ADCC and critical for NK cell mediated lysis of HIV-infected cells [11]. A minority of NK cells are CD56 ${ }^{\text {bright }}(10 \%)$, a subset that efficiently produces a variety of cytokines such as interferon- $\gamma$ (IFN- $\gamma$ ), tumor necrosis factor- $\alpha$ (TNF- $\alpha$ ), granulocyte-macrophage colony-stimulating factor (GM-CSF) and IL-10 upon activation [12]. In mice, NK cells can be characterized with the C-type lectin NK1.1 and CD49b, which in combination defines mature NK cells. Equivalent to CD56 in human NK cell subsets, murine NK cells expressing CD27 are primarily cytokine producers whereas $\mathrm{CD} 27^{-} \mathrm{CD} 11 \mathrm{~b}^{+} \mathrm{NK}$ cells exhibit a cytolytic phenotype $[13,14]$. Maturation and activation of NK cells correlates with DC activity and cytokine production whereas NK cells are also able to alter DC functions, reviewed in detail elsewhere $[15,16]$. Crosstalk between NK cells and DCs is often followed by maturation of DCs and an upregulation of NK cell effector functions. Production of type I IFN by plasmacytoid DCs (pDCs) or release of IL-12, IL-15 and IL-18 by conventional DCs as well as direct cell-cell contact result in higher cytokine production and improved cytotoxicity of NK cells [17-21]. Cytokines such as IFN- $\gamma$ and TNF- $\alpha$ produced by NK cells mediate maturation and increase functionality of DCs [22]. On the other hand, NK cells can eliminate immature DCs via recognition by the activating receptor NKp30 [19]. Additionally, production of immunosuppressive IL-10 by NK cells further dampens not only DC activation but also pleiotropic immune responses [23].

\section{HIV therapy: today and future prospects}

Currently, more than 37 million people are infected with HIV. Despite great progress in HIV research, there is still no cure from HIV infection. Treatment with antiretroviral drugs can diminish viremia below detection limit, but eradication of HIV from viral reservoirs or activation of the immune system to control HIV infection is still a task for the future. Moreover, there are numerous disadvantages of ART. ART requires life-long treatment with high costs, drug resistance development as well as side effects of the medication. There are different therapeutic approaches for new HIV therapies to overcome these problems: (1) Eradication cure with the objective to completely eliminate HIV from all compartments of the body. (2) Hybrid cure aiming at reducing viral reservoirs as well as improving virus control without the usage of ART. (3) Functional cure with the intention to control HIV replication without using ART [24]. Several of these approaches to induce HIV immune control are currently under investigation, like broadly neutralizing antibody therapies, usage of recombinant viral vectors to achieve induction of cytotoxic $\mathrm{CD} 8^{+} \mathrm{T}$ cells as well as genome editing or expansion and activation of virusspecific immune cells. Modification of NK cell activity should also be considered since NK cells can directly control retroviral infections and regulate virus-specific $\mathrm{T}$ cell responses [25].

\section{Sensing of retroviruses and the impact on NK cell responses}

Sensing of viruses is utilized by a variety of different host pattern recognition receptors (PRRs). During the replication cycle of retroviruses like HIV, simian 
immunodeficiency virus (SIV) or MuLV, various nucleic acid intermediates are generated (reviewed in [26]), which might be potential targets for endosomal or cytoplasmic sensors. Up to now, it is not completely understood, which PRRs are essential for the recognition of HIV or murine retroviruses and how this sensing further influences host immune responses. During HIV infection TLR7/8 senses GU-rich ssRNA in pDCs and monocytes leading to an antiviral state in the infected and bystander cells by the induction of type I IFN (Fig. 1) [27, 28]. Other important sensors for retroviruses located in the cytosol are RIG-I [29], cGAS [30, 31], and the IFN $\gamma$-inducible protein 16 (IFI16) [32, 33]. During murine retrovirus infections TLR3 and TLR7 are required for efficient viral sensing and induction of innate and adaptive immune responses [34-37]. During Friend Retrovirus (FV) infection of mice deficiency in TLR3 resulted in decreased IFN $\alpha$ expression and impaired NK and $\mathrm{CD}^{+}{ }^{+} \mathrm{T}$ cell cytotoxicity [37]. Immune sensing of viral infections can also induce inflammasome activation [38]. Inflammasomes are cytosolic, multimeric protein complexes that integrate several endogenous and exogenous signals. Formed inflammasomes regulate caspase- 1 , which proteolytically activates IL-1 $\beta$ and IL-18 [39], which further influences NK cell responses. It has been reported that inflammasome activation is induced during HIV infection in monocytes and macrophages [38], which may in turn influence NK cell responses.

\section{NK cell responses in retroviral infections}

Healthy cells are protected from NK cell-mediated killing primarily by the expression of Major histocompatibility complex I or Human Leukocyte antigen (HLA)-C and HLA-E. Their interaction of these molecules with inhibitory receptors on NK cells suppresses the NK cell response. Decreased expression of HLA-A and HLA-B on HIV-1 infected target cells has been described as immune evasion strategy to avoid recognition by cytotoxic $\mathrm{CD}^{+} \mathrm{T}$ cells, but this escape from adaptive immunity can render HIV-1 infected cells susceptible for NK cell killing [40]. NK cells can eliminate retrovirus infected target cells in vitro and in vivo through direct lysis or via ADCC $[7,8,41]$. Especially in acute retroviral infections (HIV-1 in humans, SIV in macaques, and FV in mice) elevated NK cell numbers and augmented cytolytic activity of NK cells could be detected [7, 42-44]. Moreover, depletion of NK cells during early FV infection showed an increase in virus infected cells in mice [7]. Activated NK cells can also produce chemokines that bind to the CCR5 receptor (MIP- $1 \alpha=$ CCL3, MIP- $1 \beta=$ CCL4, RANTES $=$ CCL5) and block the entry of R5-tropic HIV strains into $\mathrm{CD} 4^{+}$target cells by competitive prevention of receptor binding $[45,46]$. This inhibitory effect on HIV replication through chemokine release is impaired in the presence of high HIV viremia [47]. The secretion of the antiviral cytokines IFN- $\gamma$ and TNF- $\alpha$ by NK cells can also mediate suppressive effects on retrovirus replication and does not correlate with the level of plasma viremia [47, 48]. Whereas NK cells clearly play an antiviral role in acute retroviral infections, they may have different effects during the chronic infection phase. [7]. During chronic FV infection or persistent infections like LCMV, NK cells negatively regulate virus-specific $\mathrm{CD} 4^{+}$and $\mathrm{CD} 8^{+} \mathrm{T}$ cell responses, influencing adaptive immunity and possibly contributing to viral chronicity (reviewed in [49-51]). Furthermore, during other chronic viral infections, such as HIV and hepatitis $\mathrm{C}$ virus ( $\mathrm{HCV})$, a third CD56 ${ }^{\text {negative }}$ NK cell population arises (up to $15-38 \%$ of the total NK cells), which represents a dysfunctional population with lytic deficiencies and secretory dysregulations [42, 52, 53].

\section{Counter-regulation of the NK cell response by retroviruses}

Viral proteins and peptides

The importance of the NK cell response in retroviral infections became obvious when researchers discovered that HIV-1 actively counter-regulates their response. Interactions of activating receptors such as NKG2D and its ligand retinoic acid early transcript-1 (RAE-1) are essential for the activation of NK cells. In FV-infected mice, interactions of NKG2D-RAE-1 were important for NK cell-mediated killing of infected target cells [54]. Thus, retroviruses developed mechanisms to downregulate ligands for activating receptors on infected cells to escape from NK cell killing. For example, ligands for the NK cell receptors NKG2D (CD314), DNAM-1 (CD226) and NKp44 (CD336) are counter-regulated by the HIV-1 proteins Nef (negative regulatory factor) and Vpu (viral protein $\mathrm{U}$ ), an inhibitory mechanism to prevent activation of NK cells [55-58]. In plasma of HIV-1 patients the release of soluble ligands for NKG2D detuned signaling of this activating receptor and resulted in its downregulation [57].

During the last years, several combinations of NK cell receptors (KIRs) and their ligands (HLA alleles) were identified, which are beneficial or detrimental for the outcome of HIV infection and disease progression (reviewed elsewhere [59]). Interestingly, activation or inhibition of NK cells also depends on the recognition of peptides bound to HLA molecules. Recent data highlight the importance of HIV-1-derived peptides presented on HLA molecules and the impact of small mutations within these peptides for binding of NK cell receptors [60]. Especially the carboxyl terminus and in particular the residues at positions 7 and 8 seem to be of specific relevance for 


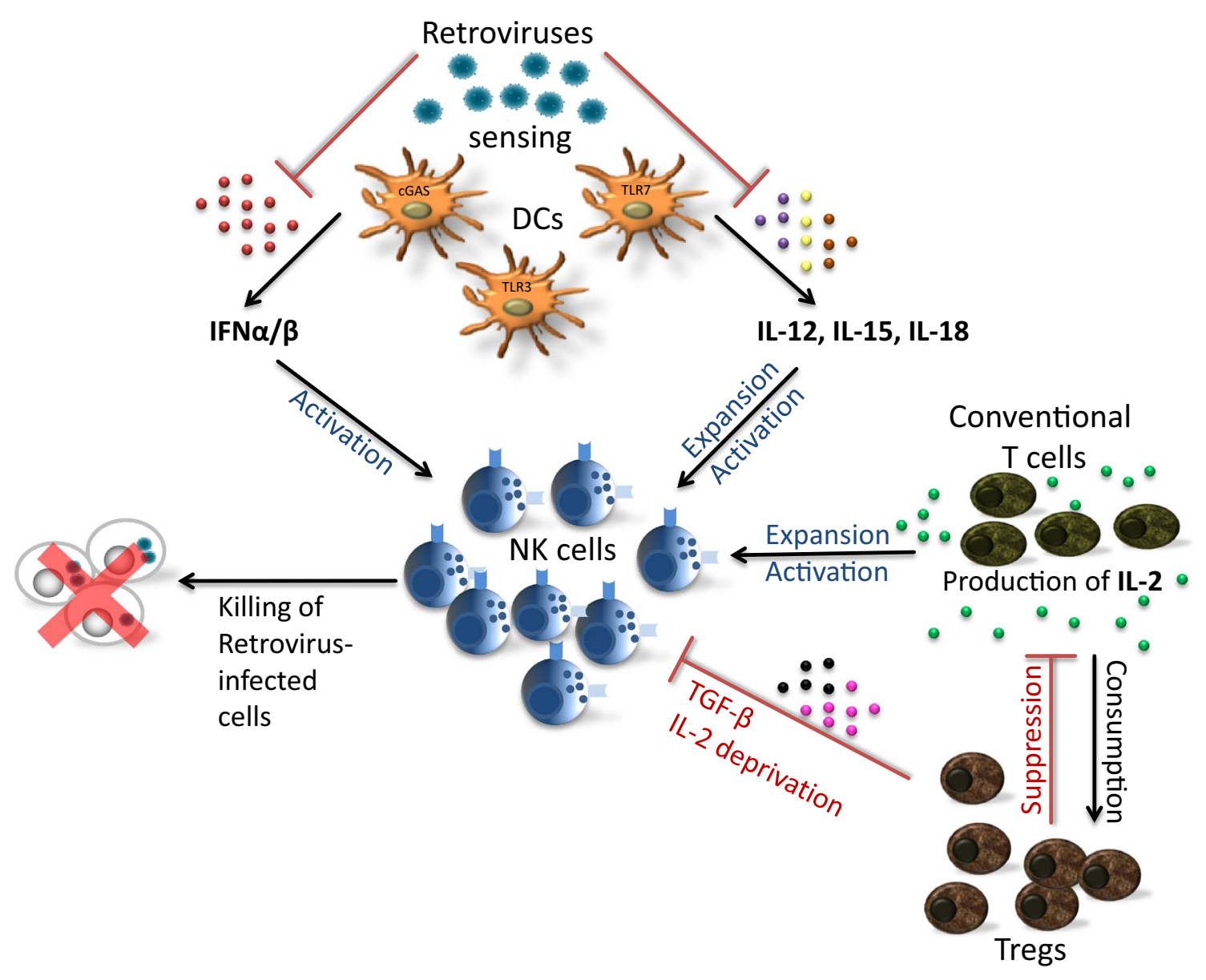

Fig. 1 NK cell influencing factors. CGAS, TLR7 and TLR3 are important for the sensing of retroviruses. The sensing results in the production of cytokines that stimulate NK cell responses. NK cells represent an important immune cell subset, which contributes to the control of retroviral infections. Retroviruses can actively suppress molecular or cellular factors that are required for NK cell activation. Immunosuppressive cytokines such as TGF- $\beta$ or cytokine deprivation by Tregs also suppress NK cell effector functions. NK cell activity can be enhanced by therapeutic stimulation with exogenous cytokines (IL-2, IL-12, IL-15, IL-18) and by IFNa/ $\beta$. CGAS cyclic GMP-AMP synthase, TLR toll-like receptors, IL interleukin, IFN interferon, TGF transforming growth factor

the initiation and the strength of binding [61]. Sequence polymorphisms within regions of HIV-1 that are targeted by inhibitory KIRs improved the binding and resulted in decreased antiviral activity of NK cells $[62,63]$. In contrast, HIV sequence mutations can also prevent binding of inhibitory receptors to HLA molecules, thereby increasing the susceptibility of infected cells to lysis [64].

\section{Immunological dysregulation of NK cell responses during retroviral infections}

Beside NK cell evasion mechanisms that are directly mediated by HIV-1 proteins or peptides, retrovirus infections can also dysregulate molecules or cells of the immune system to circumvent NK cell activation. One example is that retroviruses counter-regulate type I IFN responses, which are in turn critical for NK cell activation and differentiation (Fig. 1). It has been reported that
IFNa is only transiently induced during acute human and simian retroviral infections (HIV, SIV). Plasmacytoid DCs are the main producers of type I IFNs, but they become infected by HIV due to the expression of CD4 on their surface. As a consequence the blood pDC levels decline during HIV infection, which reduces the IFN response $[65,66]$. In addition, HIV downregulates IRF3 especially in $\mathrm{CD}^{+} \mathrm{T}$ cells and thus suppresses the induction of type I IFN $[67,68]$. During chronic HIV infection IFN- $\alpha$ might be associated with disease progression. It has been suggested that persistent IFN- $\alpha$ production by pDCs during chronic HIV infection contribute to hyper immune activation [69-71]. Blockade of IFNa receptor prevented the activation of HIV-exposed $\mathrm{CD}^{+}$ and $\mathrm{CD} 8^{+} \mathrm{T}$ cells [72]. Additionally, treatment of SIVinfected macaques with human pegylated IFN- $\alpha 2 a$ led to a decline of induced ISGs after repeated IFN application 
resulting in an IFN desensitized state [73]. Treated animals expressed elevated levels of FOXO3a, a negative regulator of IFN signaling, and increased depletion of $\mathrm{CD} 4^{+} \mathrm{T}$ cells was observed, although no changes in viral loads were detectable. During the infection of mice with murine retroviruses type I IFN is undetectable in the serum [74, 75] and Lin et al. [76] recently showed, that Moloney Leukemia Virus (MLV)-based vectors directly block the production of type I IFN in pDCs. The molecular mechanism of this suppression remains currently unknown. Our own studies with FV-infected mice have demonstrated that mice lacking the receptor for type I IFN have viral loads comparable to wild type mice [77], suggesting that the type I IFN response is significantly reduced by the virus. Nevertheless, exogenous application of type I IFN subtypes during acute FV infection can activate NK cells and reduce viral replication and infection-induced disease $[78,79]$.

During many infections myeloid DCs secrete IL-12 or IL-15 that potently induce NK cell activation and proliferation (Fig. 1). In turn, NK cells secrete cytokines like IFN- $\gamma$, TNF- $\alpha$ and GM-CSF, which lead to the maturation of myeloid DCs and further increase their cytokine production. During HIV infection, infected DCs can be found in the blood of untreated patients [80-82], however replication of the virus is very inefficient in DCs compared to activated $\mathrm{CD}^{+} \mathrm{T}$ cells $[83,84]$ due to the expression of different host restriction factors in DCs. Many studies showed that HIV-exposed or infected DCs have an altered cytokine expression profile [85-87]. In particular, the secretion of IL- 12 by myeloid DCs is strongly reduced in HIV-infected individuals resulting in decreased proliferation of NK cells and diminished IFN- $\gamma$ secretion by NK cells $[88,89]$. Similar results were also described in acutely SIV infected macaques [90]. In vitro infection of DCs with HIV also led to a defective production of IL-12 and IL-18 [91]. In contrast to IL-12 and IL-18, increased IL-15 levels were detected in the serum and lymph nodes of untreated HIV-infected individuals [92-95], which especially activates $\mathrm{CD}^{+} \mathrm{T}$ cells, but they did not analyze NK cells.

Several studies have shown that regulatory $\mathrm{T}$ cells (Tregs) can suppress homeostatic NK cell responses [96, 97]. We and others reported that acute retroviral infections (FV, HIV, SIV) expand and activate Tregs, which then suppress virus-specific $\mathrm{T}$ cell responses $[5,98,99]$. It was therefore likely that retrovirus-induced Tregs also inhibit antiviral NK cell responses. Indeed, we recently demonstrated that specific ablation of Tregs in FV infected mice improved the activation, cytokine production, and cytotoxic activity of NK cells [100]. Competition for IL-2 was found to be the main molecular mechanism of Treg-NK cell suppression (Fig. 1). The expanded
Tregs consumed large amounts of IL-2 with their highaffinity trimeric IL-2 receptor resulting in deprivation of IL-2 from NK cells, which only express the low-affinity dimeric IL-2 receptor [101, 102]. Also other suppressive mechanisms, such as the expression of TGF- $\beta$ (Transforming Growth Factor- $\beta$ ) by Tregs, have been described for the inhibition of NK cell activity [103, 104].

\section{Therapeutic approaches to augment NK cell responses in retroviral infections IFNa therapy}

Endogenous expression of type I IFNs strongly influences NK cell responses during viral infections. Type I IFNs promote NK cell activation and cytotoxicity [105-112]. IFN $\alpha$ also regulates the expression of IFN- $\gamma$ by NK cells in a Signal Transducers and Activators of Transcription (STAT) 4-dependent manner [113, 114]. Treatment of patients chronically infected with $\mathrm{HCV}$ showed that exogenous IFN $\alpha$ can polarize NK cells to a cytotoxic phenotype [115]. During acute FV infection of mice, application of IFN $\alpha$ (the IFN $\alpha 1$ and IFN $\alpha 11$ subtypes) improved NK cell responses resulting in reduced viral loads [78, 79]. This was a direct effect of IFN $\alpha$ on NK cells as shown by experiments with bone marrow chimeric mice [79]. Treatment of HIV-infected humanized mice with different subtypes of IFN $\alpha$ revealed a potent role of the subtype IFN $\alpha-14$ in reducing viremia and proviral loads [116]. Furthermore, IFN $\alpha-14$ therapy augmented the frequency of $\mathrm{TRAIL}^{+} \mathrm{NK}$ cells whereas other subtypes did not alter the NK cell response. In vivo application of IFNa also restored perforin expression of NK cells in HIVinfected patients [117]. Similar effects were observed in HIV in vitro models. NK cell lysis of HIV-infected cells was strongly enhanced by CpG treatment and this effect was mediated by type I IFN [118].

The molecular mechanisms that are involved in IFNinduced NK cell activation are still not fully understood. The expression of type I IFN induces transcription of hundreds of IFN-stimulated genes (ISGs) with direct antiviral as well as immunomodulatory properties. Some of these expressed ISGs were shown to be important in controlling retroviral replications. These host restriction factors include apolipoprotein B mRNA-editing enzyme, catalytic polypeptide-like 3G (APOBEC3G, A3G), Tetherin, SAM and HD domain-containing protein 1 (SAMHD1), tripartite motif-containing protein $5 \alpha$ (TRIM5 $\alpha$ ), Myxovirus resistance 2 (MX2), Schlafen 11 (SLFN11) and IFN-induced transmembrane proteins (IFITMs) [119, 120]. Tetherin was shown to inhibit the release of retroviruses from infected cells by tethering nascent virions to the plasma membrane [121]. Despite this direct antiviral function, IFN-induced Tetherin also improved $\mathrm{NK}$ and $\mathrm{T}$ cell responses during acute $\mathrm{FV}$ 
infection [122]. Tetherin expression mediated increased surface expression of MHC class II and the costimulatory molecule CD80, as well as the production of IL-15 by DCs, which correlated with increased IFN- $\gamma$ production and higher cytotoxicity of NK cells [123]. The authors hypothesized that the tethered virions may promote viral sensing by TLR3 or TLR7 upon endocytosis resulting in higher cytokine expression by DCs, which modulates NK cell functions. Various in vitro studies demonstrated that cells infected with HIV-1 $\Delta$ vpu cannot antagonize Tetherin. Thus, HIV-1 $\Delta$ vpu-infected cells have enhanced numbers of nascent virions tethered to the cell membrane and are indeed more susceptible to NK cell-mediated killing via ADCC [124-126]. The restriction factor A3G was also described to influence NK cell responses during retroviral infections. A3G belongs to the family of cytidine deaminases and is incorporated into progeny viruses in the absence of the HIV-1 viral infectivity factor (Vif). Upon new infections of other cells incorporated A3G deaminates cytidine to uridine during reverse transcription, resulting in hypermutations in the provirus and degradation of newly synthesized DNA strands [127, 128]. A3G can also directly inhibit reverse transcription [129]. Norman et al. demonstrated that the HIV-1 viral protein (Vpr) binds to uracil DNA glycosylase 2 (UNG2), which was activated through A3G-mediated deamination processes. This interaction induced DNA-damage repair mechanism results in higher surface expression of NKG2D ligands in infected cells and subsequently improved NK cell cytotoxicity [130]. Thus, therapeutic application of IFNa directly activates NK cells, but can also augment the expression of host restriction factors, which further augment NK cell effector functions.

\section{Stimulation of NK cells with IL-2}

IL-2 was discovered in the 1970s and was used for the first immunotherapy proved to be beneficial in patients with end-stage metastatic melanoma or renal cell carcinoma [131-134]. IL-2 was originally described as T lymphocyte stimulatory factor influencing important functions in survival, activation, proliferation and differentiation of various lymphocyte populations including NK cells [135-137]. The importance of this cytokine for NK cell activation and expansion was shown in experiments with IL-2 knockout mice [138, 139]. Interestingly, HIV elite controllers have significantly higher cytokine levels than progressors, especially for IL-2, IFN- $\gamma$ and TNF- $\alpha$ [140, 141]. NK cells in elite controllers or long-term nonprogressors reveal higher activation and increased cytotoxic activity $[142,143]$. In clinical trials with HIV progressors, treatment with IL-2 plus antiretroviral therapy increased the $\mathrm{CD} 4^{+} \mathrm{T}$ cell count but resulted in no additional clinical benefit [144]. Long-term treatment of HIV patients with intermittent IL-2 therapy mainly expanded CD $25^{+}$ $\mathrm{CD} 4^{+}$regulatory $\mathrm{T}$ cells whereas it did not alter $\mathrm{CD} 25$ or CD122 expression on NK cells [145].

One reason for the up to now unsuccessful IL-2 therapy in HIV patients might be that different receptors for IL-2 (IL-2R) exist on distinct immune cell populations. There is a trimeric, high-affinity IL-2R and a dimeric, low-affinity receptor [146]. The high-affinity IL-2R consists of the subunits IL-2R $\alpha$ (CD25), IL-2R $\beta$ (CD122) and the common $\gamma$-chain (CD132) whereas the low-affinity receptor comprises of CD122 and CD132. Memory $\mathrm{CD} 8^{+} \mathrm{T}$ cells as well as NK cells express high levels of the low-affinity dimeric IL-2R on the cell surface, however, Tregs, activated $\mathrm{CD}_{4}^{+}$and $\mathrm{CD} 8^{+} \mathrm{T}$ cells predominantly express the high-affinity IL-2R [137]. Thus, standard IL-2 therapy mainly affects $\mathrm{T}$ cells, but not NK cell responses.

IL-2/anti-IL-2 monoclonal antibody complexes can overcome this problem. IL-2 in complex with anti-mouse IL-2 mAb S4B6 or anti-human IL-2 MAB602 is preferentially directed to the CD122 receptor subunit. Treatment with specific IL-2/anti-IL-2 mAb complexes also circumvents severe side effects of high dose IL-2 therapy and results in increased half-life of IL-2 in vivo $[147,148]$. The IL-2 mAb S4B6 complex has already been shown to improve NK cell responses and subsequent clearance of tumor cells [100, 149]. In the FV model, an up to $90 \%$ reduction in viral loads was demonstrated after specific stimulation of NK cells with IL-2 mAb S4B6 complex [100]. In this study, proliferation and maturation of NK cells as well as activation and effector functions were significantly improved. The IL-2 mAb S4B6 complex therapy prohibited the consumption of the IL- 2 by Tregs and made it available for NK cell stimulation. The study shows that targeted IL- 2 therapy may be a new approach to selectively stimulate the antiviral activity of NK cells in retroviral infections.

\section{Enhancement of NK cell functions by IL-12, IL-15 or IL-18} Stimulation of NK cells with IL-2 antibody complexes is very potent for the reduction of tumor burden and viral replication but for retroviral infections complete viral control was not achieved by IL-2 stimulation so far. Combination therapy with other cytokines further augmenting NK cell functions, e.g. IL-12, IL-15 and IL-18, would be a good amendment. Interestingly, IL-15 shares numerous biologic properties with IL-2 such as the IL-2R/IL15R $\beta$-chain (CD122) and the common $\gamma$-chain (CD132), however IL-15 binds with high-affinity to its unique IL15R $\alpha$ subunit (CD215). IL-15 is indispensable for the maturation of NK cells and IL-15Ra knockout mice completely lack NK cells $[150,151]$. Similar to the biologic effect of IL-2, IL-15 efficiently activates NK cells and $\mathrm{CD}^{+} \mathrm{T}$ cells while it negligibly stimulates Tregs [101]. 
During acute HIV-1 infection, Stacey et al. [152] detected a correlation between an increase in plasma viremia and elevated IL-15 and IFN $\alpha$ levels. IL-15 levels seem to correlate with viral loads, since IL-15 therapy resulted in accelerated disease progression and augmented viral set points probably due to enhanced $\mathrm{CD}^{+}{ }^{+}$target cell proliferation [153]. Furthermore, others have shown that IL-15 levels during acute SIV infection were associated with higher susceptibility of memory $\mathrm{CD}^{+} \mathrm{T}$ cells for SIV infection [154].

However, also promising results of IL-15 therapy in retroviral infections were obtained. Stimulation of NK cells with a superagonistic IL-15 antibody increased their cytotoxic activity and was able to inhibit acute HIV-1 infection in humanized mice [155]. Injections of recombinant IL-15 increased numbers of NK cells and effector memory $\mathrm{CD}^{+} \mathrm{T}$ cells in SIV infection, but surprisingly, no changes in viral set points were detected [156]. In melanoma models it was demonstrated that stimulation of effector cells with IL-15/IL-15R $\alpha$ complexes or the IL-15 fusion protein RLI (composed of the N-terminal domain of IL-15R $\alpha$ coupled via a linker to IL-15) significantly reduced tumor burden [157]. The increased elimination of melanoma cells post treatment with RLI was NK cell dependent [157, 158]. However, such IL-15 complex therapies have so far not been tested in retroviral infection models. Thus, the role of IL-15 in NK cell activation and especially its relevance for the treatment of retroviral infections has to be further investigated in future studies.

In 1991, IL-12 was first termed "natural killer cell stimulatory factor" due to its capacity to augment NK cell cytotoxicity, but it also increases the IFN- $\gamma$ production and the lymphocyte proliferation [159]. The heterodimeric IL-12 consists of p35 and p40 subunits, which are shared by members of the IL- 12 family like IL- 23 and IL-35 [160].

In HIV-infected patients, the production of heterodimeric IL-12 is about fivefold reduced in comparison to healthy controls $[161,162]$. Thus, HIV patients may benefit from therapy with exogenous IL-12.

Treatment with the biologic active IL-12 (p70) induced high IFN- $\gamma$ levels and protected mice from murine acquired immunodeficiency syndrome (MAIDS) [163]. Furthermore, reduced viral loads and prolonged survival of acutely SIV-infected animals was observed following IL-12 administration [164]. Expectedly, IL-12 therapy strongly influenced NK cell responses. Treatment with IL-12 during acute SIV infection augmented cytotoxic responses and increased numbers of NK cells. However, only partial restoration of NK cell functions was detected after IL-12 therapy during the late phase of infection due to the loss of cytokine responsiveness $[165,166]$.
Alternatively, combination therapy with IL-2 and IL-12 increased the capacity of activated NK cells to eliminate tumor cells [167]. IL-12 in combination with the proinflammatory cytokine IL-18 synergistically enhanced NK cell activation, IFN- $\gamma$ production and proliferation, whereas during MCMV infection, activation of NK cells was more IL-18 than IL-12 dependent $[168,169]$.

IL-18 belongs to the IL-1 cytokine superfamily and is released early in response to viral infections [170]. It is constitutively produced in an inactive form (pro IL-18) and requires processing by the intracellular cysteine protease caspase- 1 for maturation from the precursor into a biologically active molecule $[171,172]$. The proinflammatory potential of IL-18 is constitutively antagonized by sustained secretion of the IL-18 binding protein (IL18BP) [173].

Infection of macaques with simian/human immunodeficiency viruses resulted in a transient increase in IL-18 serum levels at primary viremia and elevated IL-18 production was associated with seroconversion [174, 175]. More precisely, the infection with HIV resulted in decreased IL-18BP concentrations and increased levels of biological active IL-18 [176]. It was demonstrated that IL-18 inhibited the production of HIV-1 p24 antigen in vitro [177] whereas during the chronic stage of HIV-1 infection, IL-18 directly stimulated viral replication [178]. In naïve mice increased FasL-mediated cytotoxicity of NK cells and upregulation of perforin-mediated NK cell activity was detected following IL-18 administration $[179,180]$. In contrast, augmented IL-18 concentrations in chronically HIV-infected individuals were associated with increased death of NK cells [181]. Wang et al. [182] demonstrated that pre-treatment with IL-18 prior to HIV-1 infection could abrogate viral replication in vitro, predicting a potential for IL-18 treatment in HIV infection. Unfortunately, they did not analyze the involvement of NK cells in this study.

As described above, there is conflicting data about the effect of IL-18 monotherapy on NK cell responses. Nevertheless, NK cells treated with IL-18 in combination with IL-12 or triple therapy with IL-12, IL-15 and IL-18 resulted in strongly augmented NK cell degranulation and proliferation in cancer studies [183, 184]. It was also reported that pretreatment of isolated NK cells with IL-12, IL-15 and IL-18 resulted in increased antitumor activity, reduced tumor growth as well as cytokine-mediated induction of memory NK cells [185]. The efficiency and tolerability of cytokine administration depend on several factors such as administration routes, schedule of injections and the dosage. Administration of IL-12 could lead to flu-like symptoms, toxic effects on the liver and bone marrow in cancer patients, which are associated with the release of IFN- $\gamma$, TNF- $\alpha$ and chemokines 
[186]. Treatment of cancer patients with recombinant IL-15 may result in a reversible neutropenia but also in enhanced numbers of circulating NK cells and memory $\mathrm{CD}^{+} \mathrm{T}$ cells with minimal increases in Treg frequencies $[187,188]$. In melanoma patients, IL-18 therapy in biologically active doses resulted merely in mild side effects, however, monotherapy showed only limited efficacy [189, 190]. Therefore, a cytokine combination therapy may show promising therapeutic effects but was not tested as anti-retroviral treatment until now.

\section{Conclusion}

NK cells are important cytotoxic immune cells involved in the control of retroviral infections. Unfortunately, viruses developed numerous strategies to evade the immune pressure by cytolytic lymphocytes. Therefore, potent antiviral effects of NK cells in retroviral infections seem to be rather limited. Recently, therapeutic strategies to reactivate and improve NK cell functions were developed, mainly in cancer models. These new strategies are discussed in this review. Some of these approaches showed promising results in the first studies with retroviruses. A combination of these new therapies with ART might be an interesting future concept for achieving functional cure in patients that ultimately stop ART treatment.

\section{Authors' contributions}

ELS, UD and KS wrote the manuscript. All authors read and approved the final manuscript.

\section{Competing interests}

The authors declare that they have no competing interests.

\section{Funding}

ELS was supported by a grant from the University of Duisburg-Essen (IFORES). This work, including the efforts of UD and KS, was funded by Deutsche Forschungsgemeinschaft (DFG) (DFG TRR60 and GRK 1949/1).

Received: 12 August 2016 Accepted: 27 October 2016

Published online: 08 November 2016

\section{References}

1. Miyazawa M, Nishio J, Chesebro B. Protection against Friend retrovirusinduced leukemia by recombinant vaccinia viruses expressing the gag gene. J Virol. 1992;66:4497-507.

2. Chesebro B, Miyazawa M, Britt WJ. Host genetic control of spontaneous and induced immunity to Friend murine retrovirus infection. Annu Rev Immunol. 1990:8:477-99.

3. Hasenkrug KJ, Dittmer U. The role of CD4 and CD8 T cells in recovery and protection from retroviral infection: lessons from the Friend virus model. Virology. 2000;272:244-9.

4. Dittmer U, Hasenkrug KJ. Cellular and molecular mechanisms of vaccine-induced protection against retroviral infections. Curr Mol Med. 2001:1:431-6

5. Zelinskyy G, Dietze KK, Husecken YP, Schimmer S, Nair S, Werner T, Gibbert K, Kershaw O, Gruber AD, Sparwasser T, Dittmer U. The regulatory T-cell response during acute retroviral infection is locally defined and controls the magnitude and duration of the virus-specific cytotoxic T-cell response. Blood. 2009;114:3199-207.
6. Aandahl EM, Michaelsson J, Moretto WJ, Hecht FM, Nixon DF. Human $\mathrm{CD}^{+}{ }^{+} \mathrm{CD} 25^{+}$regulatory $\mathrm{T}$ cells control T-cell responses to human immunodeficiency virus and cytomegalovirus antigens. J Virol. 2004;78:2454-9.

7. Littwitz E, Francois S, Dittmer U, Gibbert K. Distinct roles of NK cells in viral immunity during different phases of acute Friend retrovirus infection. Retrovirology. 2013;10:127.

8. Bandyopadhyay S, Ziegner U, Campbell DE, Miller DS, Hoxie JA, Starr SE. Natural killer cell-mediated lysis of T cell lines chronically infected with HIV-1. Clin Exp Immunol. 1990;79:430-5.

9. Vivier E, Tomasello E, Baratin M, Walzer T, Ugolini S. Functions of natural killer cells. Nat Immunol. 2008;9:503-10.

10. Cooper MA, Fehniger TA, Caligiuri MA. The biology of human natural killer-cell subsets. Trends Immunol. 2001;22:633-40.

11. Ahmad A, Menezes J. Antibody-dependent cellular cytotoxicity in HIV infections. FASEB J. 1996:10:258-66.

12. Poli A, Michel T, Theresine M, Andres E, Hentges F, Zimmer J. CD56bright natural killer (NK) cells: an important NK cell subset. Immunology. 2009;126:458-65.

13. Chiossone L, Chaix J, Fuseri N, Roth C, Vivier E, Walzer T. Maturation of mouse NK cells is a 4-stage developmental program. Blood. 2009;113:5488-96.

14. Hayakawa Y, Huntington ND, Nutt SL, Smyth MJ. Functional subsets of mouse natural killer cells. Immunol Rev. 2006;214:47-55.

15. Altfeld M, Fadda L, Frleta D, Bhardwaj N. DCs and NK cells: critical effectors in the immune response to HIV-1. Nat Rev Immunol. 2011:11:176-86.

16. Walzer T, Dalod M, Vivier E, Zitvogel L. Natural killer cell-dendritic cell crosstalk in the initiation of immune responses. Expert Opin Biol Ther. 2005;5(Suppl 1):S49-59.

17. Gerosa F, Baldani-Guerra B, Nisii C, Marchesini V, Carra G, Trinchieri G. Reciprocal activating interaction between natural killer cells and dendritic cells. J Exp Med. 2002;195:327-33.

18. Borg C, Jalil A, Laderach D, Maruyama K, Wakasugi H, Charrier S, Ryffel B, Cambi A, Figdor C, Vainchenker W, et al. NK cell activation by dendritic cells (DCs) requires the formation of a synapse leading to IL-12 polarization in DCs. Blood. 2004;104:3267-75.

19. Ferlazzo G, Tsang ML, Moretta L, Melioli G, Steinman RM, Münz C. Human dendritic cells activate resting natural killer (NK) cells and are recognized via the NKp30 receptor by activated NK cells. J Exp Med. 2002;195:343-51.

20. Fernandez NC, Lozier A, Flament C, Ricciardi-Castagnoli P, Bellet D, Suter M, Perricaudet M, Tursz T, Maraskovsky E, Zitvogel L. Dendritic cells directly trigger NK cell functions: cross-talk relevant in innate antitumor immune responses in vivo. Nat Med. 1999;5:405-11.

21. Ferlazzo G, Pack M, Thomas D, Paludan C, Schmid D, Strowig T, Bougras G, Muller WA, Moretta L, Munz C. Distinct roles of IL-12 and IL-15 in human natural killer cell activation by dendritic cells from secondary lymphoid organs. Proc Natl Acad Sci USA. 2004;101:16606-11.

22. Piccioli D, Sbrana S, Melandri E, Valiante NM. Contact-dependent stimulation and inhibition of dendritic cells by natural killer cells. J Exp Med. 2002;195:335-41.

23. Vivier $\mathrm{E}$, Ugolini S. Regulatory natural killer cells: new players in the IL-10 anti-inflammatory response. Cell Host Microbe. 2009;6:493-5.

24. Cillo AR, Mellors JW. Which therapeutic strategy will achieve a cure for HIV-1? Curr Opin Virol. 2016;18:14-9.

25. Schuster IS, Coudert JD, Andoniou CE, Degli-Esposti MA. "Natural regulators": NK cells as modulators of T cell immunity. Front Immunol. 2016;7:235

26. Mogensen TH, Melchjorsen J, Larsen CS, Paludan SR. Innate immune recognition and activation during HIV infection. Retrovirology. 2010;7:54.

27. Beignon AS, McKenna K, Skoberne M, Manches O, DaSilva I, Kavanagh DG, Larsson M, Gorelick RJ, Lifson JD, Bhardwaj N. Endocytosis of HIV-1 activates plasmacytoid dendritic cells via Toll-like receptor-viral RNA interactions. J Clin Invest. 2005:115:3265-75.

28. Lepelley A, Louis S, Sourisseau M, Law HK, Pothlichet J, Schilte C, Chaperot L, Plumas J, Randall RE, Si-Tahar M, et al. Innate sensing of HIVinfected cells. PLoS Pathog. 2011;7:e1001284.

29. Berg RK, Melchjorsen J, Rintahaka J, Diget E, Søby S, Horan KA, Gorelick RJ, Matikainen S, Larsen CS, Ostergaard L, et al. Genomic HIV RNA 
induces innate immune responses through RIG-I-dependent sensing of secondary-structured RNA. PLoS ONE. 2012;7:e29291.

30. Gao D, Wu J, Wu YT, Du F, Aroh C, Yan N, Sun L, Chen ZJ. Cyclic GMPAMP synthase is an innate immune sensor of HIV and other retroviruses. Science. 2013;341:903-6.

31. Lahaye X. The capsids of HIV-1 and HIV-2 determine immune detection of the viral cDNA by the innate sensor CGAS in dendritic cells. Immunity. 2013;39:1132-42.

32. Monroe KM. IFI16 DNA sensor is required for death of lymphoid CD4 T cells abortively infected with HIV. Science. 2014;343:428-32.

33. Jakobsen MR. IFI16 senses DNA forms of the lentiviral replication cycle and controls HIV-1 replication. Proc Natl Acad Sci USA. 2013;110:E4571-80.

34. Browne EP, Littman DR. Myd88 is required for an antibody response to retroviral infection. PLoS Pathog. 2009;5:e1000298.

35. Browne EP. Toll-like receptor 7 inhibits early acute retroviral infection through rapid lymphocyte responses. J Virol. 2013;87:7357-66.

36. Kane M, Case LK, Wang C, Yurkovetskiy L, Dikiy S, Golovkina TV. Innate immune sensing of retroviral infection via Toll-like receptor 7 occurs upon viral entry. Immunity. 2011;35:135-45.

37. Gibbert K, Francois S, Sigmund AM, Harper MS, Barrett BS, Kirchning CJ, Lu M, Santiago ML, Dittmer U. Friend retrovirus drives cytotoxic effectors through Toll-like receptor 3. Retrovirology. 2014;11:1.

38. Chattergoon MA, Latanich R, Quinn J, Winter ME, Buckheit RW 3rd, Blankson JN, Pardoll D, Cox AL. HIV and HCV activate the inflammasome in monocytes and macrophages via endosomal Toll-like receptors without induction of type 1 interferon. PLoS Pathog. 2014;10:e1004082.

39. Latz E, Xiao TS, Stutz A. Activation and regulation of the inflammasomes. Nat Rev Immunol. 2013;13:397-411.

40. Bonaparte MI, Barker E. Killing of human immunodeficiency virusinfected primary T-cell blasts by autologous natural killer cells is dependent on the ability of the virus to alter the expression of major histocompatibility complex class I molecules. Blood. 2004;104:2087-94.

41. Tyler DS, Stanley SD, Nastala CA, Austin AA, Bartlett JA, Stine KC, Lyerly HK, Bolognesi DP, Weinhold KJ. Alterations in antibody-dependent cellular cytotoxicity during the course of HIV-1 infection. Humoral and cellular defects. J Immunol. 1990;144:3375-84.

42. Alter G, Teigen N, Davis BT, Addo MM, Suscovich TJ, Waring MT, Streeck $\mathrm{H}$, Johnston MN, Staller KD, Zaman MT, et al. Sequential deregulation of NK cell subset distribution and function starting in acute HIV-1 infection. Blood. 2005;106:3366-9.

43. Alter G, Teigen N, Ahern R, Streeck H, Meier A, Rosenberg ES, Altfeld M. Evolution of innate and adaptive effector cell functions during acute HIV-1 infection. J Infect Dis. 2007:195:1452-60.

44. Giavedoni LD, Velasquillo MC, Parodi LM, Hubbard GB, Hodara VL. Cytokine expression, natural killer cell activation, and phenotypic changes in lymphoid cells from rhesus macaques during acute infection with pathogenic simian immunodeficiency virus. J Virol. 2000;74:1648-57.

45. Oliva A, Kinter AL, Vaccarezza M, Rubbert A, Catanzaro A, Moir S, Monaco J, Ehler L, Mizell S, Jackson R, et al. Natural killer cells from human immunodeficiency virus (HIV)-infected individuals are an important source of CC-chemokines and suppress HIV-1 entry and replication in vitro. J Clin Investig. 1998;102:223-31.

46. Fehniger TA, Herbein G, Yu H, Para MI, Bernstein ZP, O'Brien WA, Caligiuri MA. Natural killer cells from HIV-1 + patients produce $\mathrm{C}-\mathrm{C}$ chemokines and inhibit HIV-1 infection. J Immunol. 1998;161:6433-8.

47. Kottilil S, Chun T-W, Moir S, Liu S, McLaughlin M, Hallahan CW, Maldarelli F, Corey L, Fauci AS. Innate immunity in human immunodeficiency virus infection: effect of viremia on natural killer cell function. J Infect Dis. 2003;187:1038-45.

48. Scott-Algara D, Truong LX, Versmisse P, David A, Luong TT, Nguyen NV, Theodorou I, Barré-Sinoussi F, Pancino G. Cutting edge: increased NK cell activity in HIV-1-exposed but uninfected Vietnamese intravascular drug users. J Immunol. 2003;171:5663-7.

49. Crome SQ, Lang PA, Lang KS, Ohashi PS. Natural killer cells regulate diverse T cell responses. Trends Immunol. 2013;34:342-9.

50. Crouse J, Xu HC, Lang PA, Oxenius A. NK cells regulating T cell responses: mechanisms and outcome. Trends Immunol. 2015;36:49-58.

51. Cook KD, Waggoner SN, Whitmire JK. NK cells and their ability to modulate T cells during virus infections. Crit Rev Immunol. 2014;34:359-88.
52. Hu PF, Hultin LE, Hultin P, Hausner MA, Hirji K, Jewett A, Bonavida B, Detels R, Giorgi JV. Natural killer cell immunodeficiency in HIV disease is manifest by profoundly decreased numbers of $\mathrm{CD} 16^{+} \mathrm{CD} 56^{+}$cells and expansion of a population of CD16dim $\mathrm{CD}^{-} 6^{-}$cells with low lytic activity. J Acquir Immune Defic Syndr Hum Retrovirol. 1995;10:331-40.

53. Gonzalez VD, Falconer K, Bjorkstrom NK, Blom KG, Weiland O, Ljunggren HG, Alaeus A, Sandberg JK. Expansion of functionally skewed CD56negative NK cells in chronic hepatitis C virus infection: correlation with outcome of pegylated IFN- $a$ and ribavirin treatment. J Immunol. 2009;183:6612-8.

54. Ogawa T, Tsuji-Kawahara S, Yuasa T, Kinoshita S, Chikaishi T, Takamura S, Matsumura H, Seya T, Saga T, Miyazawa M. Natural killer cells recognize friend retrovirus-infected erythroid progenitor cells through NKG2DRAE-1 interactions in vivo. J Virol. 2011;85:5423-35.

55. Fausther-Bovendo H, Sol-Foulon N, Candotti D, Agut H, Schwartz O, Debre P, Vieillard V. HIV escape from natural killer cytotoxicity: nef inhibits NKp44L expression on CD4 ${ }^{+}$T cells. Aids. 2009;23:1077-87.

56. Matusali G, Potesta M, Santoni A, Cerboni C, Doria M. The human immunodeficiency virus type 1 Nef and Vpu proteins downregulate the natural killer cell-activating ligand PVR. J Virol. 2012;86:4496-504.

57. Matusali G, Tchidjou HK, Pontrelli G, Bernardi S, D'Ettorre G, Vullo V, Buonomini AR, Andreoni M, Santoni A, Cerboni C, Doria M. Soluble ligands for the NKG2D receptor are released during HIV-1 infection and impair NKG2D expression and cytotoxicity of NK cells. FASEB J. 2013;27:2440-50.

58. Cerboni C, Neri F, Casartelli N, Zingoni A, Cosman D, Rossi P, Santoni A, Doria M. Human immunodeficiency virus 1 Nef protein downmodulates the ligands of the activating receptor NKG2D and inhibits natural killer cell-mediated cytotoxicity. J Gen Virol. 2007;88:242-50.

59. Hens J, Jennes W, Kestens L. The role of NK cells in HIV-1 protection: autologous, allogeneic or both? AIDS Res Ther. 2016;13:15.

60. Fadda L, Borhis G, Ahmed P, Cheent K, Pageon SV, Cazaly A, Stathopoulos S, Middleton D, Mulder A, Claas FH, et al. Peptide antagonism as a mechanism for NK cell activation. Proc Natl Acad Sci USA. 2010;107:10160-5.

61. Boyington JC, Motyka SA, Schuck P, Brooks AG, Sun PD. Crystal structure of an NK cell immunoglobulin-like receptor in complex with its class I MHC ligand. Nature. 2000;405:537-43.

62. Alter G, Heckerman D, Schneidewind A, Fadda L, Kadie CM, Carlson JM, Oniangue-Ndza C, Martin M, Li B, Khakoo Sl, et al. HIV-1 adaptation to NK-cell-mediated immune pressure. Nature. 2011;476:96-100.

63. Holzemer A, Thobakgale CF, Jimenez Cruz CA, Garcia-Beltran WF, Carlson JM, van Teijlingen NH, Mann JK, Jaggernath M, Kang SG, Korner C, et al. Selection of an HLA-C*03:04-restricted HIV-1 p24 gag sequence variant is associated with viral escape from KIR2DL3 + natural killer cells: data from an observational cohort in South Africa. PLoS Med. 2015;12:e1001900 (discussion e1001900).

64. Davis ZB, Cogswell A, Scott H, Mertsching A, Boucau J, Wambua D, Le Gall S, Planelles V, Campbell KS, Barker E. A conserved HIV-1-derived peptide presented by HLA-E renders infected T-cells highly susceptible to attack by NKG2A/CD94-bearing natural killer cells. PLoS Pathog. 2016;12:e1005421.

65. Soumelis V, Scott I, Gheyas F, Bouhour D, Cozon G, Cotte L, Huang L, Levy JA, Liu YJ. Depletion of circulating natural type 1 interferon-producing cells in HIV-infected AIDS patients. Blood. 2001;98:906-12.

66. Chehimi J, Campbell DE, Azzoni L, Bacheller D, Papasavvas E, Jerandi G, Mounzer K, Kostman J, Trinchieri G, Montaner LJ. Persistent decreases in blood plasmacytoid dendritic cell number and function despite effective highly active antiretroviral therapy and increased blood myeloid dendritic cells in HIV-infected individuals. J Immunol. 2002;168:4796-801.

67. Doehle BP, Hladik F, McNevin JP, McElrath MJ, Gale M Jr. Human immunodeficiency virus type 1 mediates global disruption of innate antiviral signaling and immune defenses within infected cells. J Virol. 2009;83:10395-405.

68. Gendelman HE, Friedman RM, Joe S, Baca LM, Turpin JA, Dveksler G, Meltzer MS, Dieffenbach C. A selective defect of interferon alpha production in human immunodeficiency virus-infected monocytes. J Exp Med. 1990;172:1433-42.

69. O'Brien M, Manches O, Sabado RL, Baranda SJ, Wang Y, Marie I, Rolnitzky L, Markowitz M, Margolis DM, Levy D, Bhardwaj N. Spatiotemporal trafficking of HIV in human plasmacytoid dendritic cells defines a 
persistently IFN-a-producing and partially matured phenotype. J Clin Investig. 2011;121:1088-101.

70. Sedaghat AR, German J, Teslovich TM, Cofrancesco J Jr, Jie CC, Talbot CC $\mathrm{Jr}$, Siliciano RF. Chronic CD4 ${ }^{+}$T-cell activation and depletion in human immunodeficiency virus type 1 infection: type I interferon-mediated disruption of T-cell dynamics. J Virol. 2008;82:1870-83.

71. Herbeuval JP, Boasso A, Grivel JC, Hardy AW, Anderson SA, Dolan MJ, Chougnet C, Lifson JD, Shearer GM. TNF-related apoptosis-inducing ligand (TRAIL) in HIV-1-infected patients and its in vitro production by antigen-presenting cells. Blood. 2005;105:2458-64.

72. Boasso A, Hardy AW, Anderson SA, Dolan MJ, Shearer GM. HIV-induced type I interferon and tryptophan catabolism drive T cell dysfunction despite phenotypic activation. PLoS ONE. 2008;3:e2961.

73. Sandler NG, Bosinger SE, Estes JD, Zhu RT, Tharp GK, Boritz E, Levin D, Wijeyesinghe S, Makamdop KN, del Prete GQ, et al. Type I interferon responses in rhesus macaques prevent SIV infection and slow disease progression. Nature. 2014;511:601-5.

74. Gerlach N, Schimmer S, Weiss S, Kalinke U, Dittmer U. Effects of type I interferons on Friend retrovirus infection. J Virol. 2006;80:3438-44.

75. Gerlach N, Schimmer S, Weiss S, Kalinke U, Dittmer U. Effects of type I interferons on Friend retrovirus infection (Erratum). J Virol. 2007;81:6160.

76. Lin AH, Burrascano C, Pettersson PL, Ibanez CE, Gruber HE, Jolly DJ. Blockade of type I interferon (IFN) production by retroviral replicating vectors and reduced tumor cell responses to IFN likely contribute to tumor selectivity. J Virol. 2014;88:10066-77.

77. Gibbert K, Dietze KK, Zelinskyy G, Lang KS, Barchet W, Kirschning CJ, Dittmer U. Polyinosinic-polycytidylic acid treatment of Friend retrovirusinfected mice improves functional properties of virus-specific $T$ cells and prevents virus-induced disease. J Immunol. 2010;185:6179-89.

78. Gerlach N, Gibbert K, Alter C, Nair S, Zelinskyy G, James CM, Dittmer U. Anti-retroviral effects of type I IFN subtypes in vivo. Eur J Immunol. 2009;39:136-46.

79. Gibbert K, Joedicke JJ, Meryk A, Trilling M, Francois S, Duppach J, Kraft A, Lang KS, Dittmer U. Interferon-alpha subtype 11 activates NK cells and enables control of retroviral infection. PLoS Pathog. 2012;8:e1002868.

80. Patterson S, Roberts MS, English NR, Macatonia SE, Gompels MN, Pinching AJ, Knight SC. Detection of HIV DNA in peripheral blood dendritic cells of HIV-infected individuals. Res Virol. 1994;145:171-6.

81. Donaghy H, Pozniak A, Gazzard B, Qazi N, Gilmour J, Gotch F, Patterson S. Loss of blood $\mathrm{CD} 11 \mathrm{C}(+)$ myeloid and $\mathrm{CD} 11 \mathrm{C}(-)$ plasmacytoid dendritic cells in patients with HIV-1 infection correlates with HIV-1 RNA virus load. Blood. 2001;98:2574-6.

82. Centlivre M, Legrand N, Steingrover R, van der Sluis R, Grijsen ML, Bakker M, Jurriaans S, Berkhout B, Paxton WA, Prins JM, Pollakis G. Altered dynamics and differential infection profiles of lymphoid and myeloid cell subsets during acute and chronic HIV-1 infection. J Leukoc Biol. 2011:89:785-95.

83. Nobile C, Petit C, Moris A, Skrabal K, Abastado JP, Mammano F, Schwartz O. Covert human immunodeficiency virus replication in dendritic cells and in DC-SIGN-expressing cells promotes long-term transmission to lymphocytes. J Virol. 2005;79:5386-99.

84. Turville SG, Santos JJ, Frank I, Cameron PU, Wilkinson J, Miranda-Saksena M, Dable J, Stossel H, Romani N, Piatak M Jr, et al. Immunodeficiency virus uptake, turnover, and 2-phase transfer in human dendritic cells. Blood. 2004:103:2170-9.

85. Smed-Sorensen A, Lore K, Walther-Jallow L, Andersson J, Spetz AL. HIV-1-infected dendritic cells up-regulate cell surface markers but fail to produce IL-12 p70 in response to CD40 ligand stimulation. Blood. 2004:104:2810-7.

86. Donaghy H, Gazzard B, Gotch F, Patterson S. Dysfunction and infection of freshly isolated blood myeloid and plasmacytoid dendritic cells in patients infected with HIV-1. Blood. 2003;101:4505-11.

87. Majumder B, Janket ML, Schafer EA, Schaubert K, Huang XL, Kan-Mitchell J, Rinaldo CR Jr, Ayyavoo V. Human immunodeficiency virus type 1 Vpr impairs dendritic cell maturation and T-cell activation: implications for viral immune escape. J Virol. 2005:79:7990-8003.

88. Mavilio D, Lombardo G, Kinter A, Fogli M, La Sala A, Ortolano S, Farschi A, Follmann D, Gregg R, Kovacs C, et al. Characterization of the defective interaction between a subset of natural killer cells and dendritic cells in HIV-1 infection. J Exp Med. 2006;203:2339-50.
89. Servet C, Zitvogel L, Hosmalin A. Dendritic cells in innate immune responses against HIV. Curr Mol Med. 2002;2:739-56.

90. Wonderlich ER, Wu WC, Normolle DP, Barratt-Boyes SM. Macrophages and myeloid dendritic cells lose T cell-stimulating function in simian immunodeficiency virus infection associated with diminished IL-12 and IFN-a production. J Immunol. 2015;195:3284-92.

91. Saidi H, Melki MT, Gougeon ML. HMGB1-dependent triggering of HIV-1 replication and persistence in dendritic cells as a consequence of NK-DC cross-talk. PLoS ONE. 2008;3:e3601.

92. Kacani L, Stoiber H, Dierich MP. Role of IL-15 in HIV-1-associated hypergammaglobulinaemia. Clin Exp Immunol. 1997:108:14-8.

93. Bastidas S, Graw F, Smith MZ, Kuster H, Gunthard HF, Oxenius A. CD8 ${ }^{+} \mathrm{T}$ cells are activated in an antigen-independent manner in HIV-infected individuals. J Immunol. 2014;192:1732-44.

94. Biancotto A, Grivel JC, Iglehart SJ, Vanpouille C, Lisco A, Sieg SF, Debernardo R, Garate K, Rodriguez B, Margolis LB, Lederman MM. Abnormal activation and cytokine spectra in lymph nodes of people chronically infected with HIV-1. Blood. 2007:109:4272-9.

95. Younes SA, Freeman ML, Mudd JC, Shive CL, Reynaldi A, Panigrahi S, Estes JD, Deleage C, Lucero C, Anderson J, et al. IL-15 promotes activation and expansion of $\mathrm{CD}^{+} \mathrm{T}$ cells in HIV-1 infection. J Clin Investig. 2016;126(7):2745-56.

96. Gasteiger G, Hemmers S, Firth MA, Le Floc'h A, Huse M, Sun JC, Rudensky AY. IL-2-dependent tuning of NK cell sensitivity for target cells is controlled by regulatory T cells. J Exp Med. 2013;210:1167-78.

97. Gasteiger G, Hemmers S, Bos PD, Sun JC, Rudensky AY. IL-2-dependent adaptive control of NK cell homeostasis. J Exp Med. 2013;210:1179-87.

98. Cao W, Jamieson BD, Hultin LE, Hultin PM, Detels R. Regulatory T cell expansion and immune activation during untreated HIV type 1 infection are associated with disease progression. AIDS Res Hum Retrovir. 2009;25:183-91.

99. Moreno-Fernandez ME, Presicce P, Chougnet CA. Homeostasis and function of regulatory T cells in HIV/SIV infection. J Virol. 2012;86:10262-9.

100. Littwitz-Salomon E, Akhmetzyanova I, Vallet C, Francois S, Dittmer U, Gibbert K. Activated regulatory T cells suppress effector NK cell responses by an IL-2-mediated mechanism during an acute retroviral infection. Retrovirology. 2015;12:66.

101. Boyman O, Krieg C, Homann D, Sprent J. Homeostatic maintenance of T cells and natural killer cells. Cell Mol Life Sci. 2012;69:1597-608.

102. Létourneau S, Krieg C, Pantaleo G, Boyman O. IL-2- and CD25-dependent immunoregulatory mechanisms in the homeostasis of T-cell subsets. J Allergy Clin Immunol. 2009;123(4):758-62. doi:10.1016/j. jaci.2009.02.011.

103. Ghiringhelli F, Menard C, Terme M, Flament C, Taieb J, Chaput N, Puig $P E$, Novault $\mathrm{S}$, Escudier B, Vivier E, et al. CD4 ${ }^{+} \mathrm{CD} 25^{+}$regulatory $T$ cells inhibit natural killer cell functions in a transforming growth factor- $\beta$ dependent manner. J Exp Med. 2005;202:1075-85.

104. Smyth MJ, Teng MW, Swann J, Kyparissoudis K, Godfrey DI, Hayakawa Y. $\mathrm{CD}^{+}{ }^{+} \mathrm{CD} 25^{+}$T regulatory cells suppress NK cell-mediated immunotherapy of cancer. J Immunol. 2006;176:1582-7.

105. Nguyen KB, Salazar-Mather TP, Dalod MY, van Deusen JB, Wei XQ, Liew FY, Caligiuri MA, Durbin JE, Biron CA. Coordinated and distinct roles for IFN- $\mathrm{A} \beta, \mathrm{IL}-12$, and IL-15 regulation of NK cell responses to viral infection. J Immunol. 2002:169:4279-87.

106. Trinchieri G. Biology of natural killer cells. Adv Immunol. 1989:47:187-376

107. Hwang I, Scott JM, Kakarla T, Duriancik DM, Choi S, Cho C, Lee T, Park $H$, French AR, Beli E, et al. Activation mechanisms of natural killer cells during influenza virus infection. PLoS ONE. 2012;7:e51858.

108. Martinez J, Huang $X$, Yang Y. Direct action of type I IFN on NK cells is required for their activation in response to vaccinia viral infection in vivo. J Immunol. 2008;180:1592-7.

109. Vogel K, Thomann S, Vogel B, Schuster P, Schmidt B. Both plasmacytoid dendritic cells and monocytes stimulate natural killer cells early during human herpes simplex virus type 1 infections. Immunology. 2014;143:588-600.

110. Lee CK, Rao DT, Gertner R, Gimeno R, Frey AB, Levy DE. Distinct requirements for IFNs and STAT1 in NK cell function. J Immunol. 2000;165:3571-7. 
111. Orange JS, Biron CA. Characterization of early IL-12, IFN- $a \beta$, and TNF effects on antiviral state and NK cell responses during murine cytomegalovirus infection. J Immunol. 1996;156:4746-56.

112. Jewett A, Bonavida B. Interferon-a activates cytotoxic function but inhibits interleukin-2-mediated proliferation and tumor necrosis factor-a secretion by immature human natural killer cells. J Clin Immunol. 1995;15:35-44.

113. Nguyen KB, Cousens LP, Doughty LA, Pien GC, Durbin JE, Biron CA Interferon $\mathrm{A} / \beta$-mediated inhibition and promotion of interferon gamma: STAT1 resolves a paradox. Nat Immunol. 2000;1:70-6.

114. Miyagi T, Gil MP, Wang X, Louten J, Chu WM, Biron CA. High basal STAT4 balanced by STAT1 induction to control type 1 interferon effects in natural killer cells. J Exp Med. 2007;204:2383-96.

115. Ahlenstiel G, Titerence RH, Koh C, Edlich B, Feld JJ, Rotman Y, Ghany MG, Hoofnagle JH, Liang TJ, Heller T, Rehermann B. Natural killer cells are polarized toward cytotoxicity in chronic hepatitis $C$ in an interferon-alfa-dependent manner. Gastroenterology. 2010;138(325-335):e321-2.

116. Lavender KJ, Gibbert K, Peterson KE, Van Dis E, Francois S, Woods T, Messer RJ, Gawanbacht A, Muller JA, Munch J, et al. Interferon alpha subtype-specific suppression of HIV-1 infection in vivo. J Virol. 2016:90:6001-13.

117. Portales P, Reynes J, Pinet V, Rouzier-Panis R, Baillat V, Clot J, Corbeau P. Interferon-a restores HIV-induced alteration of natural killer cell perforin expression in vivo. Aids. 2003;17:495-504

118. Tomescu C, Chehimi J, Maino VC, Montaner LJ. NK cell lysis of HIV1-infected autologous CD4 primary T cells: requirement for IFNmediated NK activation by plasmacytoid dendritic cells. J Immunol. 2007:179:2097-104.

119. Lu J, Pan Q, Rong L, He W, Liu SL, Liang C. The IFITM proteins inhibit HIV-1 infection. J Virol. 2011;85:2126-37.

120. Jia $X$, Zhao $Q$, Xiong $Y$. HIV suppression by host restriction factors and viral immune evasion. Curr Opin Struct Biol. 2015;31:106-14.

121. Neil SJ, Zang T, Bieniasz PD. Tetherin inhibits retrovirus release and is antagonized by HIV-1 Vpu. Nature. 2008:451:425-30.

122. Li SX, Barrett BS, Heilman KJ, Messer RJ, Liberatore RA, Bieniasz PD, Kassiotis G, Hasenkrug KJ, Santiago ML. Tetherin promotes the innate and adaptive cell-mediated immune response against retrovirus infection in vivo. J Immunol. 2014;193(1):306-16.

123. Li SX, Barrett BS, Guo K, Kassiotis G, Hasenkrug KJ, Dittmer U, Gibbert K, Santiago ML. Tetherin/BST-2 promotes dendritic cell activation and function during acute retrovirus infection. Sci Rep. 2016;6:20425.

124. Veillette M, Coutu M, Richard J, Batraville LA, Dagher O, Bernard N, Tremblay C, Kaufmann DE, Roger M, Finzi A. The HIV-1 gp120 CD4-bound conformation is preferentially targeted by antibody-dependent cellular cytotoxicity-mediating antibodies in sera from HIV-1-infected individuals. J Virol. 2015;89:545-51.

125. Alvarez RA, Hamlin RE, Monroe A, Moldt B, Hotta MT, Rodriguez Caprio G, Fierer DS, Simon V, Chen BK. HIV-1 Vpu antagonism of tetherin inhibits antibody-dependent cellular cytotoxic responses by natural killer cells. J Virol. 2014;88:6031-46.

126. Arias JF, Heyer LN, von Bredow B, Weisgrau KL, Moldt B, Burton DR, Rakasz EG, Evans DT. Tetherin antagonism by Vpu protects HIV-infected cells from antibody-dependent cell-mediated cytotoxicity. Proc Natl Acad Sci USA. 2014;111:6425-30

127. Zhang H, Yang B, Pomerantz RJ, Zhang C, Arunachalam SC, Gao L. The cytidine deaminase CEM15 induces hypermutation in newly synthesized HIV-1 DNA. Nature. 2003;424:94-8.

128. Mangeat B, Turelli P, Caron G, Friedli M, Perrin L, Trono D. Broad antiretroviral defence by human APOBEC3G through lethal editing of nascent reverse transcripts. Nature. 2003:424:99-103.

129. Bishop KN, Verma M, Kim EY, Wolinsky SM, Malim MH. APOBEC3G inhibits elongation of HIV-1 reverse transcripts. PLoS Pathog. 2008;4:e1000231.

130. Norman JM, Mashiba M, McNamara LA, Onafuwa-Nuga A, Chiari-Fort E, Shen W, Collins KL. The antiviral factor APOBEC3G enhances the recognition of HIV-infected primary T cells by natural killer cells. Nat Immunol. 2011:12:975-83.

131. Rosenberg SA. IL-2: the first effective immunotherapy for human cancer. J Immunol. 2014;192:5451-8.
132. Morgan DA, Ruscetti FW, Gallo R. Selective in vitro growth of T lymphocytes from normal human bone marrows. Science. 1976;193:1007-8.

133. Atkins MB, Lotze MT, Dutcher JP, Fisher RI, Weiss G, Margolin K, Abrams J, Sznol M, Parkinson D, Hawkins M, et al. High-dose recombinant interleukin 2 therapy for patients with metastatic melanoma: analysis of 270 patients treated between 1985 and 1993. J Clin Oncol. 1999:17:2105-16.

134. Klapper JA, Downey SG, Smith FO, Yang JC, Hughes MS, Kammula US Sherry RM, Royal RE, Steinberg SM, Rosenberg S. High-dose interleukin-2 for the treatment of metastatic renal cell carcinoma: a retrospective analysis of response and survival in patients treated in the surgery branch at the National Cancer Institute between 1986 and 2006. Cancer. 2008;113:293-301.

135. Smith KA. Interleukin-2: inception, impact, and implications. Science. 1988;240:1169-76.

136. Biron CA, Young HA, Kasaian MT. Interleukin 2-induced proliferation of murine natural killer cells in vivo. J Exp Med. 1990;171:173-88.

137. Boyman O, Sprent J. The role of interleukin-2 during homeostasis and activation of the immune system. Nat Rev Immunol. 2012;12:180-90.

138. Su HC, Orange JS, Fast LD, Chan AT, Simpson SJ, Terhorst C, Biron CA. IL-2-dependent NK cell responses discovered in virus-infected beta 2-microglobulin-deficient mice. J Immunol. 1994;153:5674-81.

139. Kundig TM, Schorle H, Bachmann MF, Hengartner H, Zinkernagel RM, Horak I. Immune responses in interleukin-2-deficient mice. Science. 1993;262:1059-61.

140. Pereyra F, Addo MM, Kaufmann DE, Liu Y, Miura T, Rathod A, Baker B,

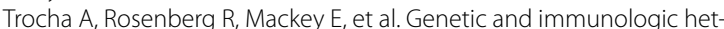
erogeneity among persons who control HIV infection in the absence of therapy. J Infect Dis. 2008;197:563-71.

141. Kannanganat S, Kapogiannis BG, Ibegbu C, Chennareddi L, Goepfert P, Robinson HL, Lennox J, Amara RR. Human immunodeficiency virus type 1 controllers but not noncontrollers maintain CD4 T cells coexpressing three cytokines. J Virol. 2007:81:12071-6.

142. Vieillard V, Fausther-Bovendo H, Samri A, Debre P. Specific phenotypic and functional features of natural killer cells from HIV-infected longterm nonprogressors and HIV controllers. J Acquir Immune Defic Syndr. 2010;53:564-73.

143. O'Connor GM, Holmes A, Mulcahy F, Gardiner CM. Natural Killer cells from long-term non-progressor HIV patients are characterized by altered phenotype and function. Clin Immunol. 2007:124:277-83.

144. Abrams D, Levy Y, Losso MH, Babiker A, Collins G, Cooper DA, Darbyshire J, Emery S, Fox L, Gordin F, et al. Interleukin-2 therapy in patients with HIV infection. N Engl J Med. 2009;361:1548-59.

145. Sereti I, Martinez-Wilson H, Metcalf JA, Baseler MW, Hallahan CW, Hahn B, Hengel RL, Davey RT, Kovacs JA, Lane HC. Long-term effects of intermittent interleukin 2 therapy in patients with HIV infection: characterization of a novel subset of CD4(+)/CD25(+)T cells. Blood. 2002;100:2159-67.

146. Taniguchi T, Minami Y. The IL-2/IL-2 receptor system: a current overview. Cell. 1993;73:5-8.

147. Arenas-Ramirez N, Woytschak J, Boyman O. Interleukin-2: biology, design and application. Trends Immunol. 2015;36:763-77.

148. Boyman O, Kovar M, Rubinstein MP, Surh CD, Sprent J. Selective stimulation of T cell subsets with antibody-cytokine immune complexes. Science. 2006:311:1924-7.

149. Jin GH, Hirano T, Murakami M. Combination treatment with IL-2 and anti-IL-2 mAbs reduces tumor metastasis via NK cell activation. Int Immunol. 2008;20:783-9.

150. Lodolce JP, Boone DL, Chai S, Swain RE, Dassopoulos T, Trettin S, Ma A IL-15 receptor maintains lymphoid homeostasis by supporting lymphocyte homing and proliferation. Immunity. 1998;9:669-76.

151. Vosshenrich CA, Samson-Villeger SI, Di Santo JP. Distinguishing features of developing natural killer cells. Curr Opin Immunol. 2005;17:151-8.

152. Stacey AR, Norris PJ, Qin L, Haygreen EA, Taylor E, Heitman J, Lebedeva M, DeCamp A, Li D, Grove D, et al. Induction of a striking systemic cytokine cascade prior to peak viremia in acute human immunodeficiency virus type 1 infection, in contrast to more modest and delayed responses in acute hepatitis B and C virus infections. J Virol. 2009:83:3719-33.

153. Mueller YM, Do DH, Altork SR, Artlett CM, Gracely EJ, Katsetos CD, Legido A, Villinger F, Altman JD, Brown CR, et al. IL-15 treatment during 
acute simian immunodeficiency virus (SIV) infection increases viral set point and accelerates disease progression despite the induction of stronger SIV-specific CD8 ${ }^{+} \mathrm{T}$ cell responses. J Immunol. 2008;180:350-60.

154. Eberly MD, Kader M, Hassan W, Rogers KA, Zhou J, Mueller YM, Mattapallii MJ, Piatak M Jr, Lifson JD, Katsikis PD, et al. Increased IL-15 production is associated with higher susceptibility of memory CD4 T cells to simian immunodeficiency virus during acute infection. J Immunol. 2009;182:1439-48.

155. Seay K, Church C, Zheng JH, Deneroff K, Ochsenbauer C, Kappes JC, Liu B, Jeng EK, Wong HC, Goldstein H. In vivo activation of human NK cells by treatment with an interleukin-15 superagonist potently inhibits acute in vivo HIV-1 infection in humanized mice. J Virol. 2015;89:6264-74.

156. Mueller YM, Petrovas C, Bojczuk PM, Dimitriou ID, Beer B, Silvera P, Villinger F, Cairns JS, Gracely EJ, Lewis MG, Katsikis PD. Interleukin-15 increases effector memory $\mathrm{CD}^{+} \mathrm{t}$ cells and NK Cells in simian immunodeficiency virus-infected macaques. J Virol. 2005;79:4877-85.

157. Bessard A, Sole V, Bouchaud G, Quemener A, Jacques Y. High antitumor activity of RLI, an interleukin-15 (IL-15)-IL-15 receptor alpha fusion protein, in metastatic melanoma and colorectal cancer. Mol Cancer Ther. 2009;8:2736-45.

158. Epardaud M, Elpek KG, Rubinstein MP, Yonekura AR, Bellemare-Pelletier A, Bronson R, Hamerman JA, Goldrath AW, Turley SJ. Interleukin-15/ interleukin-15Ra complexes promote destruction of established tumors by reviving tumor-resident CD8 ${ }^{+} T$ cells. Cancer Res. 2008;68:2972-83.

159. Wolf SF, Temple PA, Kobayashi M, Young D, Dicig M, Lowe L, Dzialo R, Fitz L, Ferenz C, Hewick RM, et al. Cloning of cDNA for natural killer cell stimulatory factor, a heterodimeric cytokine with multiple biologic effects on T and natural killer cells. J Immunol. 1991;146:3074-81.

160. Trinchieri G, Wysocka M, D’Andrea A, Rengaraju M, Aste-Amezaga M, Kubin M, Valiante NM, Chehimi J. Natural killer cell stimulatory factor (NKSF) or interleukin-12 is a key regulator of immune response and inflammation. Prog Growth Factor Res. 1992;4:355-68.

161. Chehimi J, Starr SE, Frank I, D'Andrea A, Ma X, MacGregor RR, Sennelier J, Trinchieri G. Impaired interleukin 12 production in human immunodeficiency virus-infected patients. J Exp Med. 1994;179:1361-6.

162. Ma X, Montaner LJ. Proinflammatory response and IL-12 expression in HIV-1 infection. J Leukoc Biol. 2000;68:383-90.

163. Gazzinelli RT, Giese NA, Morse HC 3rd. In vivo treatment with interleukin 12 protects mice from immune abnormalities observed during murine acquired immunodeficiency syndrome (MAIDS). J Exp Med. 1994;180:2199-208.

164. Ansari AA, Mayne AE, Sundstrom JB, Bostik P, Grimm B, Altman JD, Villinger F. Administration of recombinant rhesus interleukin-12 during acute simian immunodeficiency virus (SIV) infection leads to decreased viral loads associated with prolonged survival in SIVmac251-infected rhesus macaques. JVirol. 2002;76:1731-43.

165. Villinger F, Bucur S, Chikkala NF, Brar SS, Bostik P, Mayne AE, Adams J, Lee ME, Novembre FJ, Gately MK, et al. In vitro and in vivo responses to interleukin 12 are maintained until the late SIV infection stage but lost during AIDS. AIDS Res Hum Retrovir. 2000;16:751-63.

166. Watanabe N, Sypek JP, Mittler S, Reimann KA, Flores-Villanueva P, Voss G, Lord CI, Letvin NL. Administration of recombinant human interleukin 12 to chronically SIVmac-infected rhesus monkeys. AIDS Res Hum Retrovir. 1998;14:393-9.

167. Lehmann C, Zeis M, Uharek L. Activation of natural killer cells with interleukin 2 (IL-2) and IL-12 increases perforin binding and subsequent lysis of tumour cells. Br J Haematol. 2001;114:660-5.

168. Tyznik AJ, Verma S, Wang Q, Kronenberg M, Benedict CA. Distinct requirements for activation of NKT and NK cells during viral infection. J Immunol. 2014;192:3676-85.

169. Lauwerys BR, Renauld JC, Houssiau FA. Synergistic proliferation and activation of natural killer cells by interleukin 12 and interleukin 18 . Cytokine. 1999;11:822-30.

170. Madera S, Sun JC. Cutting edge: stage-specific requirement of IL-18 for antiviral NK cell expansion. J Immunol. 2015;194:1408-12.
171. Okamura H, Tsutsi H, Komatsu T, Yutsudo M, Hakura A, Tanimoto T, Torigoe K, Okura T, Nukada Y, Hattori K, et al. Cloning of a new cytokine that induces IFN-gamma production by T cells. Nature. 1995;378:88-91.

172. Dinarello CA, Novick D, Kim S, Kaplanski G. Interleukin-18 and IL-18 binding protein. Front Immunol. 2013;4:289.

173. Novick D, Kim S, Kaplanski G, Dinarello CA. Interleukin-18, more than a Th1 cytokine. Semin Immunol. 2013;25:439-48.

174. Kaizu M, Ami Y, Nakasone T, Sasaki Y, Izumi Y, Sato H, Takahashi E, Sakai K, Shinohara K, Nakanishi K, Honda M. Higher levels of IL-18 circulate during primary infection of monkeys with a pathogenic SHIV than with a nonpathogenic SHIV. Virology. 2003;313:8-12.

175. Song W, Wilson CM, Allen S, Wang C, Li Y, Kaslow RA, Tang J. Interleukin 18 and human immunodeficiency virus type I infection in adolescents and adults. Clin Exp Immunol. 2006;144:117-24.

176. lannello A, Boulassel MR, Samarani S, Tremblay C, Toma E, Routy JP, Ahmad A. HIV-1 causes an imbalance in the production of interleukin-18 and its natural antagonist in HIV-infected individuals: implications for enhanced viral replication. J Infect Dis. 2010;201:608-17.

177. Choi HJ, Dinarello CA, Shapiro L. Interleukin-18 inhibits human immunodeficiency virus type 1 production in peripheral blood mononuclear cells. J Infect Dis. 2001;184:560-8.

178. Torre D, Pugliese A, Speranza F, Martegani R, Tambini R. Role of interleukin-18 in human immunodeficiency virus type 1 infection. J Infect Dis. 2002;185:998 (author reply 998-999).

179. Hyodo Y, Matsui K, Hayashi N, Tsutsui H, Kashiwamura S, Yamauchi H, Hiroishi K, Takeda K, Tagawa Y, Iwakura Y, et al. IL-18 up-regulates perforin-mediated NK activity without increasing perforin messenger RNA expression by binding to constitutively expressed IL-18 receptor. J Immunol. 1999;162:1662-8.

180. Tsutsui H, Nakanishi K, Matsui K, Higashino K, Okamura H, Miyazawa Y, Kaneda K. IFN-gamma-inducing factor up-regulates Fas ligand-mediated cytotoxic activity of murine natural killer cell clones. J Immunol. 1996;157:3967-73.

181. Iannello A, Samarani S, Debbeche O, Ahmad R, Boulassel MR, Tremblay C, Toma E, Routy JP, Ahmad A. Potential role of interleukin-18 in the immunopathogenesis of AIDS: involvement in fratricidal killing of NK cells. J Virol. 2009:83:5999-6010.

182. Wang $X$, Mbondji-Wonje C, Zhao J, Hewlett I. IL-1 $\beta$ and IL-18 inhibition of HIV-1 replication in Jurkat cells and PBMCs. Biochem Biophys Res Commun. 2016:473:926-30

183. Mirjacic Martinovic K, Babovic N, Dzodic R, Jurisic V, Matkovic S, Konjevic $\mathrm{G}$. Favorable in vitro effects of combined IL-12 and IL-18 treatment on NK cell cytotoxicity and CD25 receptor expression in metastatic melanoma patients. J Transl Med. 2015:13:120

184. Ni J, Miller M, Stojanovic A, Garbi N, Cerwenka A. Sustained effector function of IL-12/15/18-preactivated NK cells against established tumors. J Exp Med. 2012;209:2351-65.

185. Min-Oo G, Kamimura Y, Hendricks DW, Nabekura T, Lanier LL. Natural killer cells: walking three paths down memory lane. Trends Immunol. 2013;34:251-8.

186. Lasek W, Zagozdzon R, Jakobisiak M. Interleukin 12: still a promising candidate for tumor immunotherapy? Cancer Immunol Immunother. 2014;63:419-35.

187. Steel JC, Waldmann TA, Morris JC. Interleukin-15 biology and its therapeutic implications in cancer. Trends Pharmacol Sci. 2012;33:35-41.

188. Conlon KC, Lugli E, Welles HC, Rosenberg SA, Fojo AT, Morris JC, Fleisher TA, Dubois SP, Perera LP, Stewart DM, et al. Redistribution, hyperproliferation, activation of natural killer cells and CD8 T cells, and cytokine production during first-in-human clinical trial of recombinant human interleukin-15 in patients with cancer. J Clin Oncol. 2015;33:74-82.

189. Srivastava S, Salim N, Robertson MJ. Interleukin-18: biology and role in the immunotherapy of cancer. Curr Med Chem. 2010;17:3353-7.

190. Robertson MJ, Kirkwood JM, Logan TF, Koch KM, Kathman S, Kirby LC, Bell WN, Thurmond LM, Weisenbach J, Dar MM. A dose-escalation study of recombinant human interleukin-18 using two different schedules of administration in patients with cancer. Clin Cancer Res. 2008;14:3462-9. 